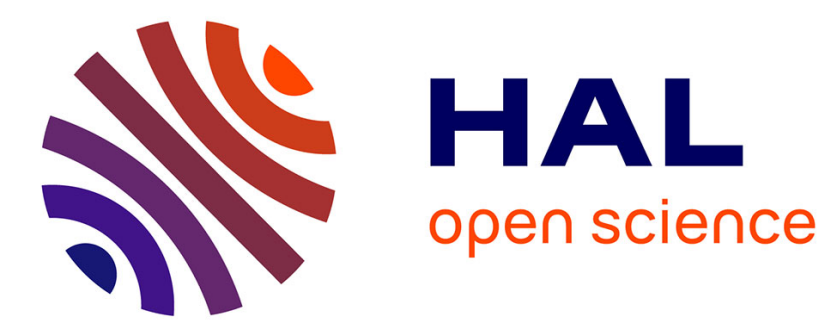

\title{
EBSD-measured lattice-preferred orientations and seismic properties of eclogites
}

Jerôme Bascou, Guilhem Barruol, Alain Vauchez, David Mainprice, Marcos

Egydio-Silva

\section{- To cite this version:}

Jerôme Bascou, Guilhem Barruol, Alain Vauchez, David Mainprice, Marcos Egydio-Silva. EBSDmeasured lattice-preferred orientations and seismic properties of eclogites. Tectonophysics, 2001, 342, pp.61 - 80. 10.1016/S0040-1951(01)00156-1 . hal-01389715

\section{HAL Id: hal-01389715 \\ https://hal.univ-reunion.fr/hal-01389715}

Submitted on 29 Oct 2016

HAL is a multi-disciplinary open access archive for the deposit and dissemination of scientific research documents, whether they are published or not. The documents may come from teaching and research institutions in France or abroad, or from public or private research centers.
L'archive ouverte pluridisciplinaire HAL, est destinée au dépôt et à la diffusion de documents scientifiques de niveau recherche, publiés ou non, émanant des établissements d'enseignement et de recherche français ou étrangers, des laboratoires publics ou privés. 


\title{
EBSD-measured lattice-preferred orientations and seismic properties of eclogites
}

\author{
Jérôme Bascou a,b,*, Guilhem Barruol ${ }^{\mathrm{a}}$, Alain Vauchez ${ }^{\mathrm{a}}$, David Mainprice ${ }^{\mathrm{a}}$, \\ Marcos Egydio-Silva ${ }^{\mathrm{b}}$ \\ ${ }^{a}$ Laboratoire de Tectonophysique, Université de Montpellier II and CNRS UMR 5568-cc049, Place E. Bataillon, \\ 34095 Montpellier cedex 5, France \\ ${ }^{\mathrm{b}}$ Instituto de Geociências, Universidade de São Paulo, Rua do lago 562, Cep: 05508-900, C.P. 11358 São Paulo, Brazil
}

Received 10 July 2000; accepted 3 December 2000

\begin{abstract}
We investigated the deformation mechanisms and the seismic properties of 10 eclogite samples from different localities (Alps, Norway, Mali and eastern China) through the analysis of their microstructures and lattice-preferred orientations (LPO). These samples are representative of various types and intensity of deformation under eclogitic metamorphic conditions. Omphacite and garnet LPO were determined from electron backscatter diffraction (EBSD) technique. Garnet appears to be almost randomly oriented whereas omphacite develops strong LPO, characterized by the [001]-axes concentrated sub-parallel to the lineation, and the (010)-poles concentrated sub-perpendicular to the foliation. In order to analyze the deformation mechanisms that produced such omphacite LPO, we compare our observations to LPO simulated by viscoplastic selfconsistent numerical models. A good fit to the measured LPO is obtained for models in which the dominant slip systems are $1 / 2\langle 110\rangle\{1 \overline{1} 0\},[001]\{110\}$ and [001] (100). Dominant activation of these slip systems is in agreement with TEM studies of naturally deformed omphacite. Seismic properties of eclogite are calculated by combining the measured LPO and the single crystal elastic constants of omphacite and garnet. Although eclogite seismic anisotropies are very weak (less than 3\% for both P- and S-wave), they are generally characterized by a maximum P-wave velocity sub-parallel to the lineation and by a minimum velocity approximately normal to foliation. The mean P- and S-wave velocities are high (respectively, 8.6 and 4.9 $\mathrm{km} / \mathrm{s}$ ). The S-wave anisotropy pattern displays complex relationships with the structural frame but the fast polarization plane generally tends to be parallel to the foliation. Calculated reflection coefficients show that an eclogite/crust interface is generally a good reflector $(\mathrm{Rc}>0.1)$, whereas an eclogite body embedded in the upper mantle would be hardly detectable. (C) 2001 Elsevier Science B.V. All rights reserved.
\end{abstract}

Keywords: Electron backscatter diffraction (EBSD); Lattice-preferred orientation (LPO); Omphacite deformation; Numerical models; Seismic anisotropy; Reflectivity

\section{Introduction}

* Corresponding author. Laboratoire de Tectonophysique, Université de Montpellier II et CNRS UMR 5568-cc049, Place E. Bataillon, 34095 Montpellier cedex 5, France.

E-mail address: bascou@dstu.univ-montp2.fr (J. Bascou).
High-pressure rocks in collisional orogens are often regarded as relicts of subduction zones. Their detection is therefore fundamental in the understanding of the earth's dynamic. In particular, the pres- 
ence of eclogite bodies within the continental lithosphere could explain high velocity patches detected in seismic tomography models or bright seismic reflectors on deep seismic reflection profiles (Butler, 1986; Laubscher, 1990; Nicolas et al., 1990; Austrheim, 1991; Warner et al., 1996). Laboratory measurements of P- and S-wave velocities (e.g. Fountain et al., 1994; Kern et al., 1999) show that eclogites are characterized by $\mathrm{P}$-wave velocities around 8.0 $\mathrm{km} / \mathrm{s}$, which are much faster than the average Pwave velocities of other crustal rock (e.g. Barruol and Mainprice, 1993a; Christensen and Mooney 1995). These velocities are however similar to the average velocity in the uppermost mantle, i.e., 8.09 $\mathrm{km} / \mathrm{s}$ for the Pn-average velocity.

Possible effects of seismic anisotropy on the reflectivity of eclogite bodies in contact with peridotite have been pointed out by Mauler et al. (2000). Unfortunately, if peridotite seismic anisotropy and its relationship with olivine lattice-preferred orientation is widely documented (Babuska, 1972; Nicolas et al., 1973; Nicolas and Christensen, 1987; Ben Ismaill and Mainprice, 1998), it is not the case of eclogitic rocks seismic properties. Eclogites seismic anisotropy is also expected to be controlled by the anisotropy of the elastic properties of omphacite single-crystal (Bhagat et al., 1992), but the relationship between the omphacite LPO, the deformation mechanisms and the resulting seismic properties is poorly documented (Godard and Van Roermund, 1995).

The overall aim of this paper is therefore to increase our knowledge on the eclogite physical properties. To access this point, (1) we quantify the crystallographic orientations of omphacite and garnet in eclogites sampled from various localities (Alps, Norway, Mali and eastern China) that display different types and intensity of deformation; (2) we discuss the deformation mechanisms that produce the measured omphacite LPO. The lack of experimental data on omphacite polycrystals deformation stimulates us to perform numerical models of LPO development by dislocation glide in order to constrain the relationship between LPO and slip systems activity; (3) we compute the seismic properties ( $\mathrm{P}$ and $\mathrm{S}$ velocities) of the selected eclogites from their measured LPO; and (4) we finally discuss the reflectivity of horizontal interfaces involving eclogite, crustal and mantle rocks.

\section{Geological settings and textures description}

\subsection{Alpe Arami eclogites (Alps)}

The Alpe Arami peridotite massif is located within the Lepontine gneisses, north from the Insubric Line (Fig. 1). This lens-shaped peridotite massif, 1-km long, is surrounded by eclogite boudins partly converted to an amphibolite assemblage (Möckel, 1969; Ernst, 1977). Thermobarometric investigations (Heinrich, 1986) suggest $P-T$ metamorphic conditions in the range $1.8-3.5 \mathrm{GPa}$ and $750-900{ }^{\circ} \mathrm{C}$.

Sample AB.E is petrologicaly representative of the eclogitic event. It contains $60 \%$ of omphacite, $30 \%$ of garnet and rutile, ca-amphibole and kyanite as accessory minerals. This rock is characterized by a penetrative foliation and a lineation marked by a shape-preferred orientation of omphacite crystals. The largest omphacite crystals are more than 4-mm long (Fig. 2a). The garnet crystals, weakly elongated, are roughly $800-\mu \mathrm{m}$ long in average and contain inclusions of omphacite.

\subsection{Mt Mucrone eclogites (Alps)}

In the Monte Mucrone area (Fig. 1), glaucophanebearing eclogitic boudins are embedded in the SesiaLanzo zone micaschists. These eclogites are characterized by a good preservation of the high-pressure mineralogical assemblages (Lardeaux et al., 1982; Rubie, 1984) and might represent a slice of Austroalpine continental crust subducted during the cretaceous Alpine collision (e.g. Compagnoni et al., 1977). The metamorphic conditions are estimated to be around $1.4-1.6 \mathrm{GPa}$ and $500-560{ }^{\circ} \mathrm{C}$ (Lardeaux et al., 1982).

Sample eclo 01 is composed of omphacite (55\%), garnet $(25 \%)$, zoisite $(10 \%)$ and minor phengite, glaucophane and rutile. The microstructure is characterized by a bimodal distribution of omphacite grain size with large porphyroclasts $(>2 \mathrm{~mm}$ ) surrounded by fine-grained recrystallized omphacite. The largest grains show undulose extinction and subgrain boundaries (Fig. 2b). Another class of omphacite crystals is made of elongated grains about 2-mm long that are free of sub-structure. The foliation is marked by zoisite-rich layers and the elongation of omphacite porphyroclasts. 

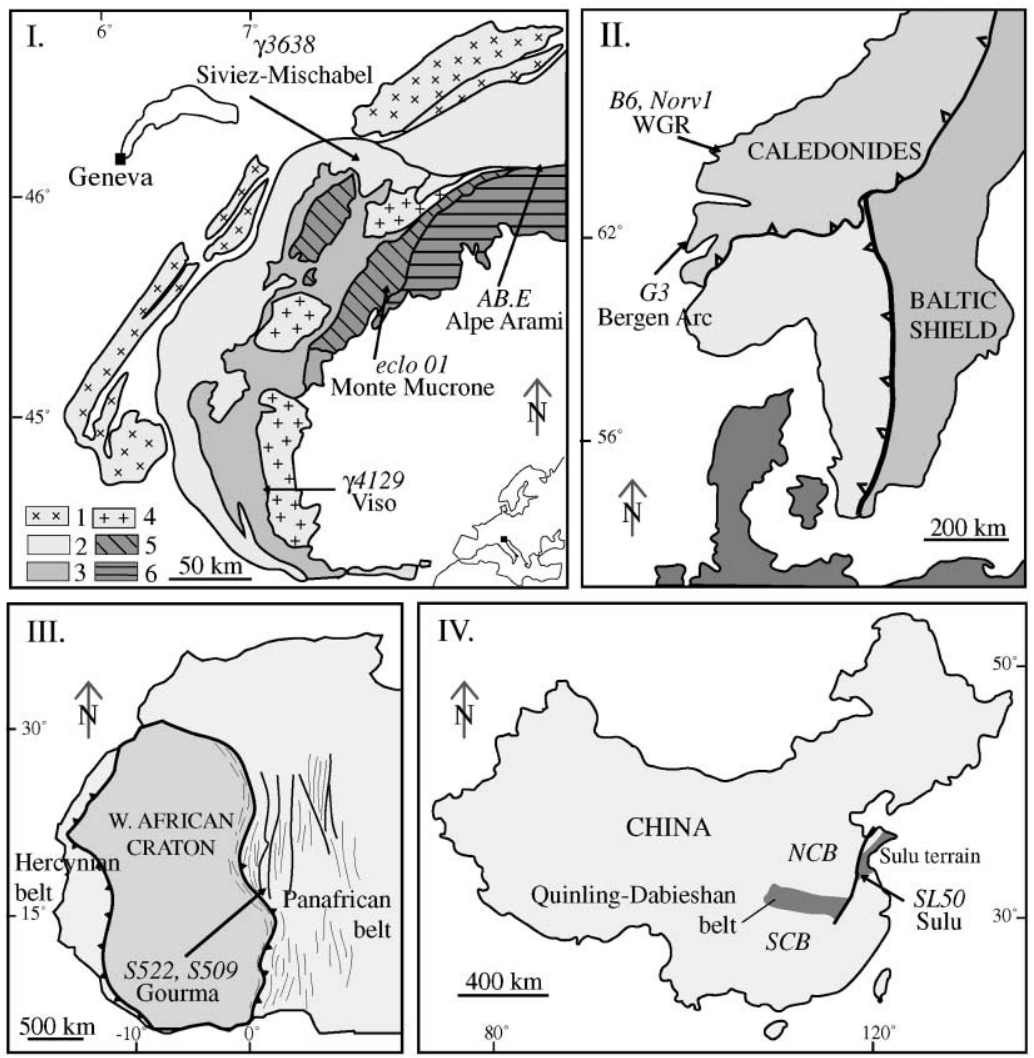

Fig. 1. Schematic maps showing the geographical and geological setting of the studied eclogite samples. (I) Alps region: AB.E, Alpe Arami massif; eclo 01, Monte Mucrone; $\gamma 4129$, Monviso Complex; $\gamma 3638$ Siviez-Mischabel nappe. $1=$ Helvetic basement; $2=$ Penninic realm undifferentiated; 3 = Piemonte zone (Penninic); $4=$ Monte Rosa, Gran Paradiso and Dora Maira nappes (Penninic basement); $5=$ Sesia Zone and Dent Blanche nappe; $6=$ South Alpine units. (II) Norway area: G3 (Holsnøy island), Bergen Arc; B6 and Norv.1, Western Gneiss Region (WGR). (III) Mali area: S522 and S509, Gourma basin. (IV) Dabie and Sulu areas: SL50, Sulu terrain. NCB= North China Block, and $\mathrm{SCB}=$ South China Block.

\subsection{Monviso eclogites (Alps)}

The Monviso meta-ophiolitic complex is located in the Western Alps (Fig. 1). Eclogitic metamorphism is related to the subduction of an oceanic crust during the Alpine orogeny (e.g. Caby et al., 1978). The pressure and temperature conditions of the eclogitic metamorphism have been estimated to be $2.4 \mathrm{GPa}$ and $620 \pm 50{ }^{\circ} \mathrm{C}$ (Messiga et al., 1999).

Sample $\gamma 4129(65 \%$ omphacite, $20 \%$ garnet, $8 \%$ rutile) was collected within the highly deformed, eclogitic metagabbros outcropping in the Lago Superior Unit (Philippot and Kienast, 1989). This sample is characterized by a mylonitic foliation formed by fine $(<40 \mu \mathrm{m})$, recrystallized omphacite grains. Some large omphacite grains (>1 mm; Fig. $2 \mathrm{c})$ are remnants of the original texture; they display undulose extinction and subgrain boundaries. Garnet grains are small $(500 \mu \mathrm{m})$ and rounded. Fine layers of elongated and fragmented rutile grains underline the foliation and the lineation.

\subsection{Siviez-Mischabel nappe eclogites (Alps)}

These eclogites are located in the polymetamorphic basement of the Penninic Siviez-Mischabel nappe (Valais, Switzerland; Fig. 1). Eclogitization was not generated during Alpine orogeny but is supposed to have occurred during Paleozoic times at a temperature around $650{ }^{\circ} \mathrm{C}$ and a pressure above $1.5 \mathrm{GPa}$ (Thélin et al., 1990). Lately, the high-pressure mineral assem- 

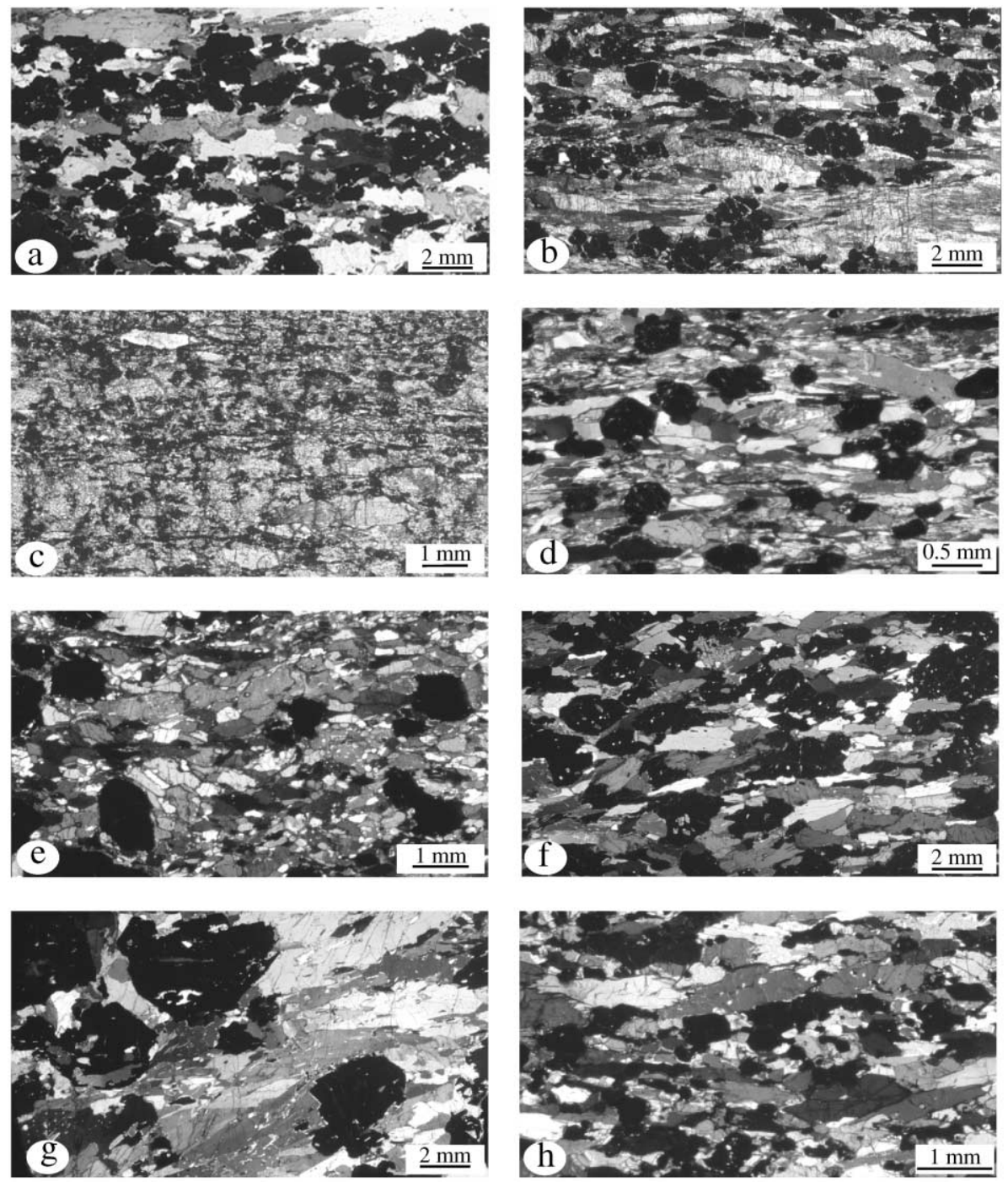

Fig. 2. Photomicrographs showing typical microstructures of eclogite samples. (a) Sample AB.E; (b) sample eclo 01; (c) sample $\gamma 4129$; (d) sample $\gamma 3638$; (e) sample G3; (f) sample B6; (g) sample Norv1; (h) sample S522. Thin sections in the XZ structural plane except g; g contains $X$-axis and makes an angle of $60^{\circ}$ with the $X Y$ plane. Polarized light.

blage has been partially retrogressed in the amphibolite- and greenschist-facies.

Sample $\gamma 3638$ was collected in the core of a decametric-scale boudin enclosed in retrogressed gneisses. Its modal composition is primarily omphacite $(65 \%)$ and garnet $(20 \%)$. White mica, zoisite and kyanite are present as accessory components. In thin section (Fig. 2d), elongated crystals of omphacite as well as mica, zoisite and rutile underline the foliation.
Omphacite grains are sub-automorphous and about $500-\mu \mathrm{m}$ long. Garnet grains are fractured and rounded.

\subsection{Bergen Arc eclogites (Norway)}

The eclogites of series $\mathrm{G}$ (three samples) have been collected on Holsnøy Island (Western Norway; Fig. 1), within the Hundskjeften shear zone that crosscut granulite facies anorthositic complex of the Bergen 
Arc. This complex formed during the Proterozoic Grenvillian orogeny (i.e., $1 \mathrm{Ga}$ ) was subsequently strongly deformed and partially eclogitized during the Caledonian orogeny (Austrheim and Griffin, 1985; Austrheim, 1987). The pressure and temperature conditions of eclogitization were estimated to be around $1.8 \mathrm{GPa}$ and $700-800{ }^{\circ} \mathrm{C}$ (Austrheim and Griffin, 1985).

The three samples of the series $G$ are fine grained and display similar modal content. Thus, we only present one of those samples (G3) in Fig. 2e; it is composed of omphacite (65\%), garnet $(25 \%)$ and minor phengite, zoisite and kyanite. Sub-automorphous omphacite crystals, 200-500- $\mu \mathrm{m}$ long, mark the foliation. Garnet generally is rounded and generally millimetric in size. The other mineralogical phases are strongly elongated in the foliation.

\subsection{Western Gneiss Region eclogites (Norway)}

These eclogites are located within the Western Gneiss Region (WGR; Fig. 1), north of the Nordfjord-Sogn Detachment. This detachment was active during the late to post orogenic extension of the Caledonides and is thought to have played an important role in the exhumation of the WGR (Andersen, 1998).

Sample B6 is sampled from the core of an eclogite boudin that was retrogressed in the amphibolite metamorphic facies. In the core of this boudin, eclogite facies parageneses are still preserved. B6 contains $55 \%$ omphacite, $35 \%$ garnet plus minor quartz, phengite and rutile. Omphacite grains up to $2-\mathrm{mm}$ long display a weak symplectization. A shape-preferred orientation of omphacite crystals marks the foliation and lineation. Garnet is inclusion-rich and millimetric in size (Fig. 2f).

Sample Norv1 (not in-situ) was collected in the Nordfjord area (Fig. 1). Mineral composition is omphacite $(60 \%)$, garnet (30\%), with kyanite, zoisite, phengite and quartz as minor components. This sample is coarse-grained with omphacite grains $>4 \mathrm{~mm}$ and large garnets ( $>3 \mathrm{~mm}$; Fig. $2 \mathrm{~g}$ ) showing abundant amphibole and quartz inclusions.

\subsection{Gourma eclogites (Mali)}

Samples S522 and S509 represent eclogitic metasediments from the internal nappes of the Gourma area, northern Mali (Fig. 1). These eclogites are thought to represent sediments of a passive continental margin subducted during the closure of a pre-PanAfrican ocean. They might be exhumed during the Pan-African collision of the West African craton with an arc and/or with the Hoggar-Iforas continental margin (Caby, 1994). The eclogitic metamorphism occurred at pressure above $2.7 \mathrm{GPa}$ and temperature ranging between 700 and $750{ }^{\circ} \mathrm{C}$ (Caby, 1994).

In the calc-silicate sample S522 (Fig. 2h), coesite relics in omphacite have been described by Caby (1994). Omphacite represents the major mineral phase (70\%). The other phases are garnet, quartz, ankerite and accessory rutile and phengite. A penetrative foliation is defined by the shape fabric of tabular omphacite crystals $(>1.5 \mathrm{~mm})$. Garnet crystals are millimetric in size and rounded in shape. A finegrained matrix contains omphacite grains of about $400 \mu \mathrm{m}$, quartz and ankerite.

Sample S509 was collected in a metabasic sill within micaschists. This sample is characterized by a mineralogical layering of omphacite-rich (+ quartz) and omphacite-poor, garnet-rich layers. In the omphacite-rich layers, omphacite displays evidence of an overgrowth with megacrysts above $1.5 \mathrm{~cm}$ in length containing abundant quartz inclusions. In omphacitepoor, garnet-rich layers, the grain size of omphacite and garnet is relatively homogeneous $(1-2 \mathrm{~mm})$.

\subsection{Sulu eclogites (eastern China)}

Dabie and Sulu areas are considered as the eastern extension of the Quinling-Dabishan orogenic belt, which results from a collision between the North and South China Blocks (Fig. 1). The occurrence of coesite in the Dabie and Sulu gneissic and eclogitic terranes indicates a subduction of the South China continental crust down to more than $100 \mathrm{~km}$ (e.g. Faure et al., 2001). In the Sulu terrain, the $P, T$ conditions were evaluated at ca. $700-890{ }^{\circ} \mathrm{C}$ and $P>2.8$ GPa (Zhang et al., 1995).

Studied eclogites were sampled in the southern part of the Sulu terrain. The less retromorphozed sample (SL50) is made of omphacite (70\%), garnet (20\%), quartz $(7 \%)$ and minor phengite, epidote, rutile and kyanite. Elongated crystals of omphacite (about $1 \times 3$ $\mathrm{mm}$ in size) underline the foliation and lineation. Garnet grains of about $0.8 \mathrm{~mm}$ are equidimensional 
and quartz grains up to 1-mm long are strongly deformed.

\section{Electron backscatter diffraction (EBSD) measurements}

\subsection{Experimental setup and indexing procedure}

Omphacite and garnet lattice-preferred orientations (LPO) were measured on a scanning electron microscope JEOL JSM 5600 by electron backscatter diffraction techniques (EBSD; Lloyd et al., 1991; Adams et al., 1993; Dingley and Field, 1997). This technique is based on automatic analysis of diffraction patterns. These patterns composed of Kikuchi bands are generated by interaction of a vertical incident electron beam with a flat crystal surface. We used polished thin sections about $10 \mathrm{~cm}^{2}$ and tilted at $70^{\circ}$ from the horizontal within the microscope chamber. A phosphor screen is located close to the thin section to collect the backscattered electrons and to emit a photonic image of the EBSD pattern. A low-light, high-resolution camera acquires this photonic image, which is then processed and indexed using the CHANNEL + software (Schmidt and Olesen, 1989). At each point of measurement, the Euler angles $(\varphi 1, \phi, \varphi 2)$ characterizing the lattice orientation of the crystal are determined and stored together with the nature of the mineral. The whole procedure (pattern acquisition, image freezing, band detection, indexing and result backup) can be carried out automatically. The relative precision of crystal orientations measured from electron backscattering patterns is better than $1^{\circ}$ (Krieger Lassen, 1996).

In order to improve the quality of the diffraction patterns, relief on the thin section is minimized by a careful polishing. The polishing procedure ends with a $1 / 4-\mu \mathrm{m}$ diamond paste followed by a SYTON chemical polishing. In addition, charging effect were prevented by a slight platinum coating. EBSP were acquired at accelerating voltage of $15 \mathrm{kV}$ and a working distance of about $40 \mathrm{~mm}$.

Crystal orientation is determined by comparing the observed pattern of Kikuchi bands with those simulated for a pre-defined crystallographic structure. For each investigated mineral phase, one has therefore to generate first the crystallographic structure file
(Laüe group, unit cell parameters, atoms position within the unit cell) and calculate the corresponding database file containing the reflectors suitable for the best indexing. For garnet, we used a set of the 64 strongest reflections bands calculated from pyrope structure of cell edge $11.459 \AA$. For omphacite, we used a set of the 73 strongest Kikuchi bands calculated using the crystallographic data of a Norway omphacite (Clark et al., 1969). The weak impact on the reflection of the $\mathrm{C} 2 / \mathrm{c}$ to $\mathrm{P} 2 / \mathrm{n}$ ordering structure transformation (Mauler et al., 1998) in the omphacite compositional range, allows using a single omphacite hkl-file. Lattice-preferred orientations were measured in automatic mode when no electronic charging artifacts affected the pattern quality. Otherwise, we used a manual procedure. During automatic measurements, we used discriminators in order to reject suspicious indexings. These discriminators give a control on the pattern quality (band contrast and band slope parameters), but also on the indexation velocity (search rounds parameter) and on the quality of the agreement between detected and simulated Kikuchi bands (Mean Angular Deviation parameter). Data that did not fulfill the parameters were rejected. The diffraction pattern of mineral other than omphacite and garnet, as for example, kyanite, systematically produced a zero solution. For all the samples, the whole surface of the thin sections was investigated. Finally, the stage motorization allows a stepby-step measurement on a predefined grid. We choose a step size of the same order as the omphacite grain size of the studied sample (see Table 1), except for the sample Norv1, whose grain size was too large. In most cases, the relative small size of the mean grains relative to the thin section area secures a good sampling statistic in spite of a possible oversampling of the largest grains. In "manual" procedure, only the step size along the $Y$ direction was imposed, whereas along the $X$ direction, each new pattern was indexed by the operator avoiding duplicate measurements in the same grains (Table 1 summarizes all methodological information). For each sample, both omphacite and garnet were indexed. If omphacite displays significant latticepreferred orientations, it is not the case for garnet that is almost randomly oriented. For this reason, we concentrate our following microstructural analyze on omphacite. 
Table 1

$P, T$ conditions of eclogitic metamorphism, analytic data and grain size for the studied samples

\begin{tabular}{|c|c|c|c|c|c|c|}
\hline Samples & Sample location & $P(\mathrm{GPA}), T\left({ }^{\circ} \mathrm{C}\right)$ peak & $\begin{array}{l}\text { Mean } \\
\text { reference }\end{array}$ & $\begin{array}{l}\text { EBSD } \\
\text { procedure }\end{array}$ & Step $(\mu \mathrm{m})$ & Mean grain size $(\mu \mathrm{m})$ \\
\hline \multicolumn{7}{|c|}{ Alpine eclogites } \\
\hline AB.E & Alpe Arami & $1.8-3.5,750-900$ & {$[1]$} & manual & $y: 1000$ & omph: $4000 \times 1000$; grt: 800 \\
\hline Eclo 01 & Mt. Mucrone & $1.3-1.6,600-650$ & [2] & automatic & $x, y: 500$ & $\begin{array}{l}\text { omph: } 3000 \times 1000(\text { porph}) \\
<1000 \text { (recr); grt: } 1000\end{array}$ \\
\hline$\gamma 4129$ & Monviso & $>2.4,570-670$ & {$[3]$} & manual & $y: 500$ & $\begin{array}{l}\text { omph: } 2000 \times 500 \text { (porph); } \\
<40 \text { (recr); grt: } 500 \times 300\end{array}$ \\
\hline$\gamma 3638$ & Siviez-Mischabel & $>1.5,620-680$ & {$[4]$} & automatic & $x, y: 500$ & $\begin{array}{l}\text { omph: } 500 \times 200 \text {, matrix }<300 \text {; } \\
\text { grt: } 500\end{array}$ \\
\hline \multicolumn{7}{|c|}{ Norway eclogites } \\
\hline G1 & Bergen Arcs & $>1.8,700-750$ & {$[5]$} & manual & $y: 500$ & omph: $500 \times 50$; grt: 15000 \\
\hline $\mathrm{G} 2$ & & & & automatic & $x, y: 300$ & $\begin{array}{l}\text { omph1: } 1000 \times 300 \\
\text { omph2: } 200 \text {; grt: } 2000\end{array}$ \\
\hline G3 & & & & automatic & $x, y: 400$ & $\begin{array}{l}\text { omph: } 500 \times 200 \\
\text { grt: } 1000 \times 1500\end{array}$ \\
\hline \multicolumn{7}{|c|}{ Western gneiss region } \\
\hline $\begin{array}{l}\text { B6 } \\
\text { Norv.1 }\end{array}$ & $\begin{array}{l}\text { Nordfjord area } \\
\text { (Verpeneset ) }\end{array}$ & $1.4-1.6,650-700$ & {$[6]$} & $\begin{array}{l}\text { manual } \\
\text { automatic }\end{array}$ & $x, y: 1000$ & $\begin{array}{l}\text { omph: } 3000 \times 1000 \text {; grt: } 2000 \\
\text { omph }>4000 ; \text { grt }>3000\end{array}$ \\
\hline \multicolumn{7}{|c|}{ Gourma eclogites } \\
\hline S522 & & $>2.7,700-750$ & {$[7]$} & manual & $y: 1000$ & $\begin{array}{l}\text { omph: } 1500 \times 800 \text { and } \\
400 \times 200 ; \text { grt }<1000\end{array}$ \\
\hline S509 & & $>2.7,700-750$ & {$[7]$} & manual & $y: 1000$ & omph> 1000; grt:1000 \\
\hline \multicolumn{7}{|c|}{ Sulu eclogites } \\
\hline SL50 & & $>2.8,700-890$ & {$[8]$} & automatic & $x, y: 1000$ & omph: $3000 \times 1000 ;$ grt $<1000$ \\
\hline
\end{tabular}

Omph: omphacite; grt: garnet; porph: porphyroclasts; recr: recrystallized grains. Figs. 3 and 5 give the number of measurement $(N)$ of omphacite per sample. [1] Heinrich (1986); [2] Lardeaux et al. (1982); [3] Messiga et al. (1999); [4] Thélin et al. (1990); [5] Austrheim and Griffin (1985); [6] Krogh (1982); [7] Caby (1994); [8] Zhang et al. (1995).

\subsection{Omphacite lattice-preferred orientations}

Omphacite LPO is generally measured from thin section cut parallel to the structural $(X Z)$-plane, i.e., normal to the foliation and parallel to the lineation. The well-marked mineralogical foliation and lineation characterizing our samples ensures a good precision in the determination of the orientation of the structural $X$-, $Y$-, and $Z$-axis ( $X=$ lineation; $Z=$ pole of the foliation). The measured omphacite LPO (Figs. 3, 4 and 5) are presented on equal area, lower hemisphere projections in the structural $(X Z)$ reference frame. Foliation is vertical $E-W$ and the lineation is horizontal in this plane. Only sample Norv1 was not cut parallel the (XZ)-plane and LPO of this sample was rotated a posteriori for easier comparison with the others samples.
Omphacite LPO (Figs. 3, 4 and 5) are characterized by strong concentrations of (010)-poles and [001]axes normal to the foliation and parallel to the lineation, respectively. [100]-axes and (110)-poles are poorly oriented. However, (110)-poles tend to concentrate in a girdle perpendicular to the lineation with a maximum at ca. $60^{\circ}$ to the foliation. [100]-axes display a maximum of concentration close to the $Y$ structural axis (i.e., normal to the lineation within the foliation) is often observed.

Besides these general features, LPO variations are observed from sample to sample. Sample AB.E from Alpe Arami (Fig. 3) displays the best concentration of (010)-poles close to the $Z$-axis. A weak but significant obliquity (about $7^{\circ}$ ) is observed between the maximum of density of [001]-axes and the lineation. For this sample, three thin sections in the $X Z$ plane were 


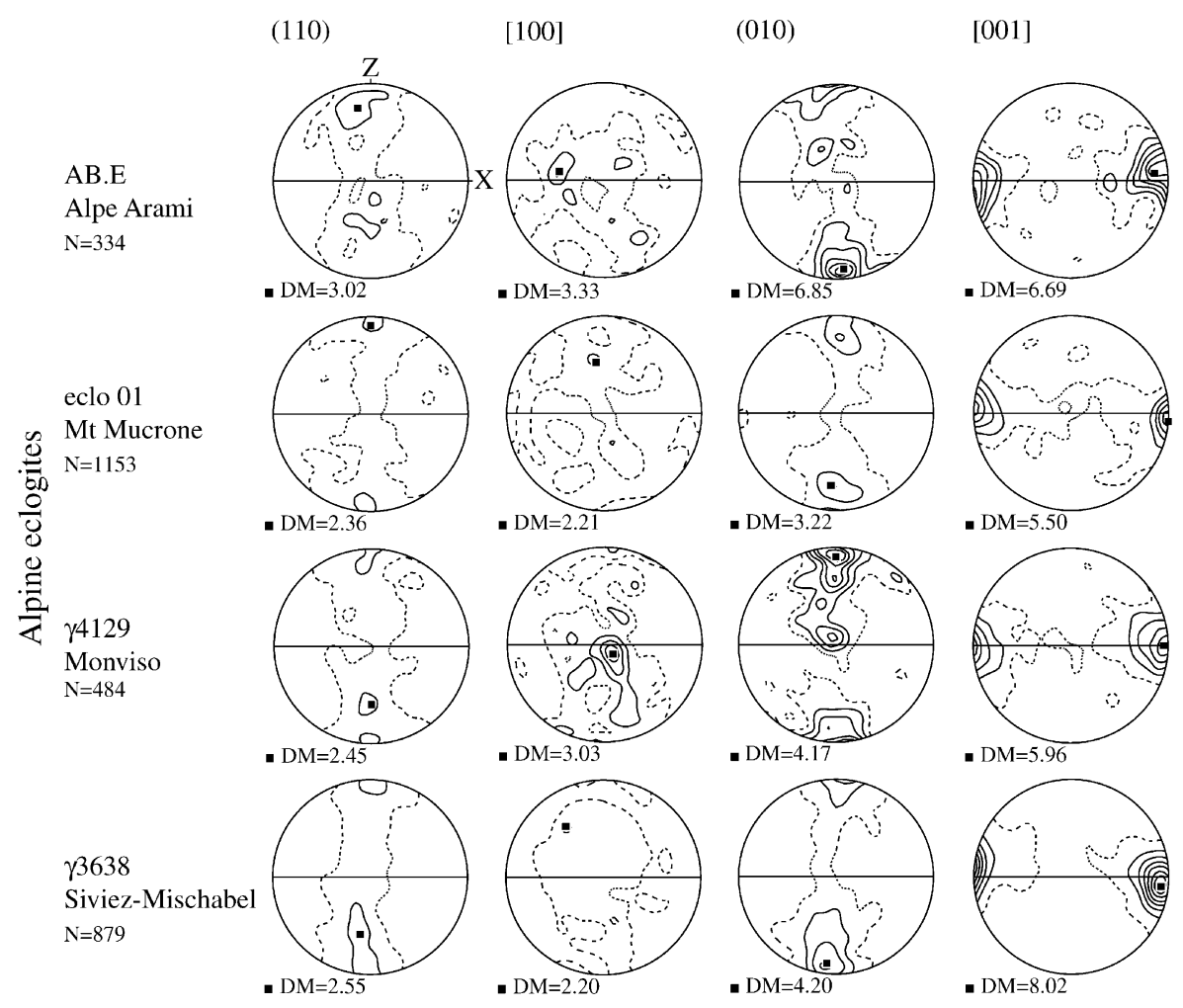

Fig. 3. Omphacite LPO of Alpine eclogites measured using EBSD technique. Equal area projection, lower hemisphere. Contours $1,2,3 \%$. . by $1 \%$ area. Foliation ( $X Y$ plane; full line) is vertical and lineation $(X)$ is horizontal in this plane. $N$ : number of measurements. DM: maximum density.

manually measured on a 5-axis universal stage mounted on an optical microscope (Fig. 4). The LPO measured from EBSD technique and from a 5- axis universal stage are very similar. Especially, we observe for both techniques an obliquity between the maximum concentration of [001]-axes and the line-

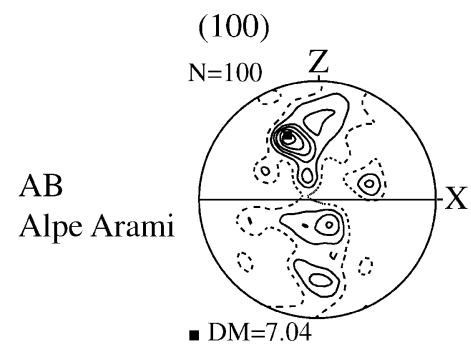

(010)

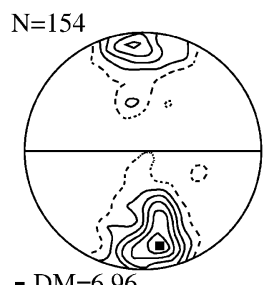

[001]

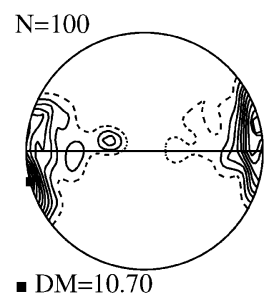

Fig. 4. Omphacite LPO of Alpe Arami eclogite measured using a 5-axes universal stage. Equal area projection, lower hemisphere. Contours 1, 2, $3 \%$. . by $1 \%$ area. Foliation ( $X Y$ plane; full line) is vertical and lineation $(X)$ is horizontal in this plane. $N$ : number of measurements. DM: maximum density. 

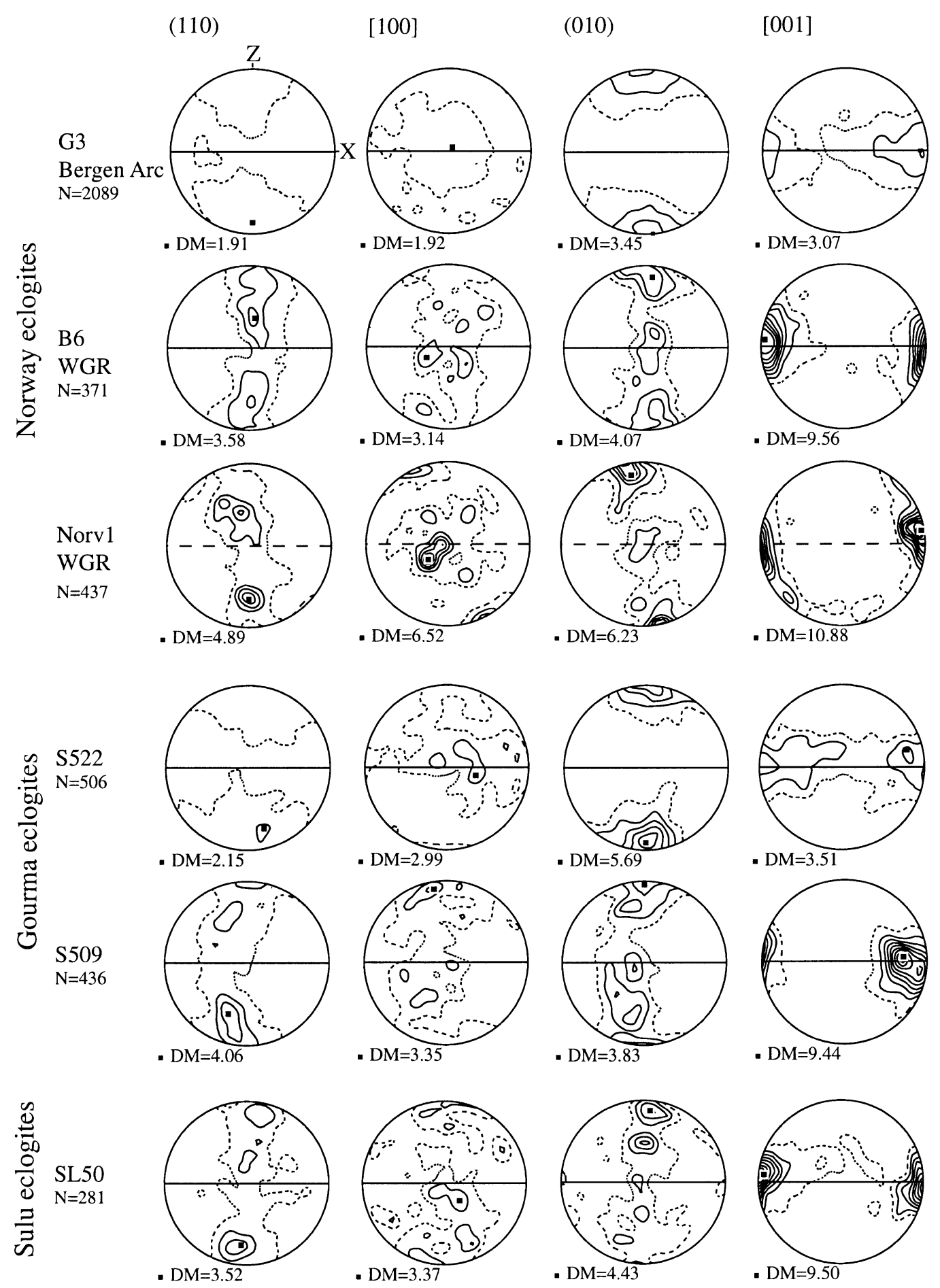

Fig. 5. Omphacite LPO of Norway and Gourma eclogite samples. EBSD measurements. Equal area projection, lower hemisphere. Contours 1, 2, $3 \%$. . by $1 \%$ area. Foliation ( $X Y$ plane; full line) is vertical and lineation $(X)$ is horizontal in this plane. $N$ : number of measurements. DM: maximum density. 
ation. Discrepancies between LPO patterns may be related partly to lower precision of measurement derived from U-stage optical technique (which is expected to be about $5^{\circ}$ ) relative to the EBSD technique $\left(<1^{\circ}\right.$; Mainprice et al., 1993; Krieger Lassen, 1996). Moreover, the higher concentration of omphacite LPOs derived from universal stage measurements may be due to grain selection. Indeed, due to the monoclinic symmetry of omphacite crystals, only the grains showing a cleavage plane, such as $\{110\}$, can be measured at the universal stage.

Samples eclo 01, $\gamma 4129, \gamma 3638$ (Fig. 3), B6, Norv1, S509 and SL50 (Fig. 5) are characterized by a strong [001] maximum sub-parallel to the lineation. These samples (except $\gamma 4129$ ) present a slight obliquity between the maximum of [001]-axes concentration and the lineation. The concentration of (010)poles is weaker than one [001]-axis and (010)-poles tend to form a girdle perpendicular to the lineation. Moreover, (010)-poles of samples $\gamma 4129$, B6 and Norv1 are grouped in two maxima: the strongest maximum is close to the $Z$-axis and the weakest is close to the $Y$-axis. Also, sample SL50 shows two maxima located between the $Z$ - and $Y$-axis: the strongest is close to the $Z$-axis and the weakest is at ca. $45^{\circ}$ from the $Z$-axis. Sample eclo 01 shows (010)-poles located between the $Z$ - and $Y$-axis and (110)-poles close to the $Z$-axis, whereas for the other samples the maximum of density of (010)-poles stands close to the $Z$-axis and the maximum of (110) is located between the $Z$ - and $Y$-axis. Sample Norv1 displays [100]-axes close to $Y$ with a weaker sub-maximum at ca. $20^{\circ}$ from $Z$. However, the larger concentration of LPO for Norv1 may be due to oversampling of the largest omphacite crystals. Sample S509 is characterized by a clustering of [001]-axes in the foliation at ca. $20^{\circ}$ from $X$. [100]-axes show a weak maximum of density normal to the foliation. (010)-poles and (110)-poles tend to form a girdle perpendicular to the lineation with a density maximum close to the $Z$-axis.

The three samples of the series $G$ (we only present G3 in Fig. 5) from Norway present similar LPO characterized by weak density maxima. The maximum of (010)-poles concentration is normal to the
(110)

Simple Shear

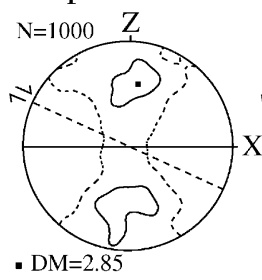

[100]

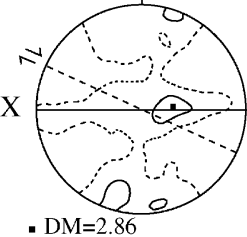

(010)

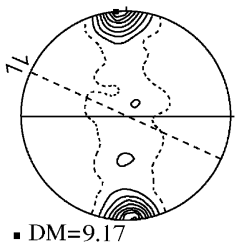

- $\mathrm{DM}=7.14$

[001]

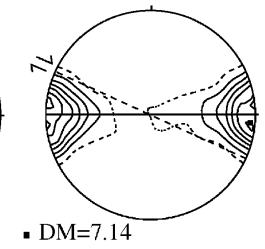

Axial Compression
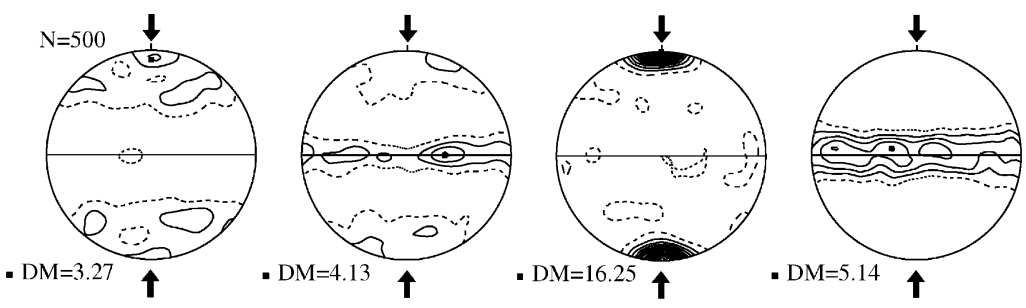

Fig. 6. Omphacite LPO simulated using an anisotropic viscoplastic self-consistent (VPSC) model in simple shear and axial compression (Bascou et al., 2001). These LPOs are developed for an equivalent strain of 1 . Equal area projection, lower hemisphere. Contours $1,2,3 \%$. . by $1 \%$ area. Full line: foliation ( $X Y$ plane) is vertical and lineation $(X)$ is horizontal. Dotted line: shear direction $(\gamma=1.73) . N$ : Number of grains. DM: maximum density. 
foliation and the [001]-axes tend to form a girdle in the foliation plane.

Sample S522 from Gourma area (Fig. 5) is characterized by [001]-axes scattered in the foliation plane and (010)-poles strongly concentrated close to $Z$. (110)-poles and [100]-axes display weak preferred orientations. However, (110)-poles present a weak maximum near the normal to the foliation.

\subsection{Omphacite LPO significance}

Variations in omphacite LPO are generally related to the strain regime (Helmstaedt et al., 1972; Boundy et al., 1992; Godard and Van Roermund, 1995; Abalos, 1997). Omphacite LPO of samples AB.E, eclo 01, $\gamma 4129, \gamma 3638$, B6, Norv1, S509 and SL50 are similar to the L-type or LS-type LPO pattern defined by Helmstaedt et al. (1972) as resulting from constriction strain. On the other hand, samples S522 and G3 display LPO similar to the S-type or SL-type, interpreted as resulting from flattening (Helmstaedt et al., 1972; Godard and Van Roermund, 1995; Abalos, 1997). The asymmetric omphacite LPO observed for samples AB.E, $\gamma 3638$ (Fig. 3) and samples B6, Norv1 and SL50 may result from a noncoaxial deformation and the obliquity between the LPO and the $X, Y$ and $Z$ structural axes could be related to the sense of shear (Bouchez et al., 1983; Mainprice and Nicolas, 1989). Asymmetric omphacite LPO were already described by Boundy et al (1992) within eclogitized metagabbro dykes from the Bergen Arc, and by Abalos (1997) who used this obliquity to deduce the sense of shear.

In plastically deformed rocks, the LPO development due to intracrystalline slip is well established. For most minerals (e.g. olivine), when one slip system is predominant during deformation, the slip direction and the slip plane tend to coincide with the flow direction and the flow plane, respectively (Mainprice and Nicolas, 1989). Thus, the strong preferred orientation of [001]-axes parallel to the lineation and (010)poles perpendicular to the foliation that characterizes the omphacite LPO in naturally deformed eclogites, suggest a dominant activation of the [001] (010) slip system. However, dislocations associated with this slip system have rarely been observed in naturally deformed omphacite. The dominant slip systems identified from TEM observations are $1 / 2\langle 110\rangle\{1 \overline{1} 0\}$, [001] $\{110\}$ and [001] (100) (Van Roermund and
Boland, 1981; Van Roermund, 1983; Buatier et al., 1991; Godard and Van Roermund, 1995).

In order to better understand the deformation mechanisms that could have produced the omphacite LPO, we compared the LPO of naturally deformed omphacite with those simulated by numerical models (Bascou et al., 2001). In polycrystal plasticity models, like the anisotropic viscoplastic self-consistent model (VPSC) developed by Lebensohn and Tomé (1993) and applied to mantle rocks by Tommasi et al. (2000), the LPO evolution is directly related to the slip systems activity. Fig. 6 displays some modeled omphacite LPO developed in simple shear and axial compression. The relative strength (Critical Resolved Shear Stresses) of the various omphacite slip systems (Table 2) are derived from naturally deformed omphacites TEM observations of dislocations (lowest CRSS values have been affected to those systems whose dislocations are the most frequently observed).

Simulated LPO display general characteristics similar to those observed in the LPO measured in naturally deformed eclogites. In particular, modeled omphacite LPO developed in simple shear deformation $(\gamma=1.73)$ reproduces well LPO observed for

Table 2

Slip systems data used to simulate the omphacite deformation (Bascou et al., 2001)

\begin{tabular}{ll}
\hline Slip system & CRSS $^{\mathrm{a}}$ \\
\hline$[001](100)$ & 1 \\
{$[001](110)$} & 1 \\
{$[001](1 \overline{1} 0)$} & 1 \\
{$[1 \overline{1} 0](110)$} & 1 \\
{$[110](1 \overline{1} 0)$} & 1 \\
{$[001](010)$} & 8 \\
{$[1 \overline{1} 2](110)$} & 8 \\
{$[112](1 \overline{1} 0)$} & 8 \\
{$[010](100)$} & 8 \\
{$[1 \overline{1} \overline{2}](110)$} & 8 \\
{$[11 \overline{2}](1 \overline{1} 0)$} & 8 \\
{$[100](010)$} & 8 \\
{$[101](010)$} & 8 \\
\hline
\end{tabular}

The various potential slip systems considered come from diopside deformation experiments (Raterron et al, 1994).

${ }^{\text {a }}$ Critical Resolved Shear Stress. For this model, lowest CRSS values have been affected to those systems whose dislocations are the most frequently observed in the TEM analyses of omphacite naturally deformed (see text). 
sample AB.E (Fig. 3). Likewise, omphacite LPO predicted to develop under axial compression reproduces well LPO observed for sample S522 (Fig. 5). Interestingly, a strong preferred orientation of the (010)-poles is developed during these simulations even when the [001] (010) slip system is not activated.

The good agreement between the omphacite LPO measured in naturally deformed eclogites and the LPO simulated using a self-consistent polycrystal plasticity model suggests that omphacite LPO may be generated by dominant slip on the $1 / 2\langle 110\rangle\{1 \overline{1} 0\},[001]\{110\}$ and [001] (100) systems. These models may reconcile the interpretation of the measured omphacite LPO in eclogites and TEM observations of dislocations in naturally deformed omphacite. From our measurements, we propose that most of the omphacite LPOs could have developed through plastic deformation during noncoaxial strain under eclogitic conditions. These LPOs are therefore related to the tectonic history of eclogites.

\section{Eclogite seismic properties}

\subsection{Seismic properties calculation}

Seismic velocities are calculated from the Christoffel equation (Crosson and Lin, 1971) that takes into account each single crystal elastic stiffness matrix, the crystals orientation and density. The knowledge of the single crystal elastic constants and the LPO of each rock-forming mineral allows to determine the $6 \times 6$ elastic stiffness matrix characterizing the elastic behavior of each mineral phase (Mainprice, 1990). The rock elastic stiffness matrix is computed taking into account the elastic matrix of each mineral phase according to its modal proportion in the rock. In the calculation, we only take into account the major mineral phases of eclogitic metamorphism (i.e., omphacite, garnet, and epidote). For sample SL50 from the Sulu terrain, we also considered the contribution of quartz in the seismic properties. Seismic calculations were carried out using the single crystal elastic constants measured at room temperature and atmospheric pressure by Bhagat et al. (1992) for omphacite (30\% diopside, $58 \%$ jadeite), Babuska et al. (1978) for garnet (40\% pyrope, 40\% almandin, $20 \%$ grossular) and McSkimin et al. (1965) for quartz. For sample eclo 01 containing $10 \%$ of epidote, we used the epidote elastic constants reported by Ryzhova et al. (1966) but we assumed this mineral as randomly oriented.

The omphacite single crystal seismic properties are presented in Fig. 7. The maximum P-wave velocities $(9.37 \mathrm{~km} / \mathrm{s})$ is at ca. $30^{\circ}$ from the [001] direction which is also a direction of fast propagation $(9.0 \mathrm{~km} /$ s). A girdle of lower velocity contains the (010)-pole. The P-wave anisotropy (AVp) defined as $100 \times[\mathrm{Vp}$ $\max -\mathrm{Vp} \min ) /((\mathrm{Vp} \max +\mathrm{Vp} \min ) / 2)]$ is rather high $(20.4 \%)$ for the omphacite. The S-wave anisotropy is

Omphacite single crystal

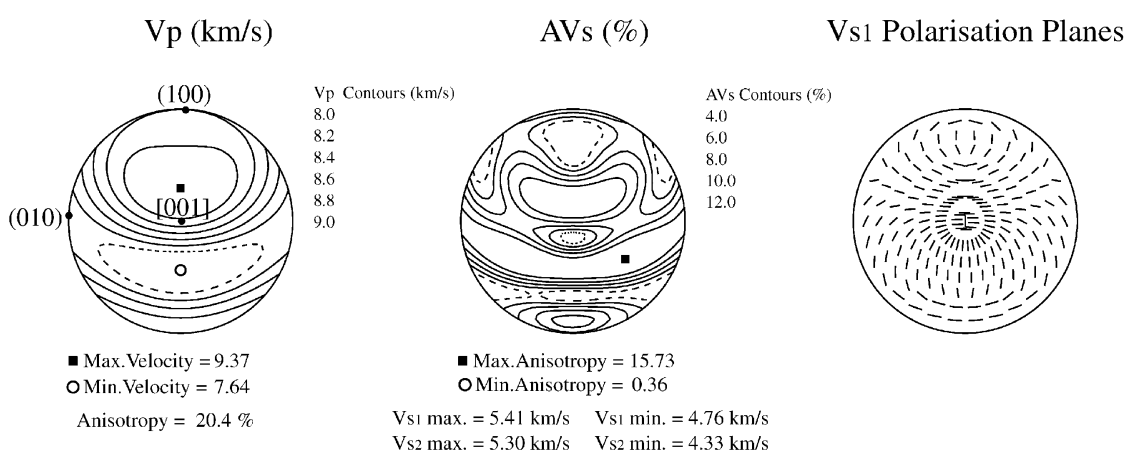

Fig. 7. Seismic properties of the omphacite single crystal. Equal area projection, lower hemisphere. 
defined for each propagation direction as $100 \times$ $\left.\left[\mathrm{Vs}_{1}-\mathrm{Vs}_{2}\right) /\left(\left(\mathrm{Vs}_{1}+\mathrm{Vs}_{2}\right) / 2\right)\right]$. The S-wave anisotropy is characterized by a complex pattern with three zones of high anisotropy $(>10 \%)$ containing the $(010)$-pole and [001]-axis. The orientation of the fast S-wave polarization plane has rather complex relationship with the crystallographic axis.

\subsection{Eclogite seismic properties}

The seismic properties of the selected eclogites are summarized in Table 3 and the $3 \mathrm{D}$ results are shown in equal area projection (Fig. 8). The P-wave velocity patterns of eclogite samples are rather similar. The fast $\mathrm{P}$-wave velocity ( $\mathrm{Vp} \max$ ) ranges from 8.51 to $8.75 \mathrm{~km} / \mathrm{s}$ and its propagation direction is generally close to the $X$-axis. The low velocity (Vp $\min$ ) ranges from 8.39 to $8.62 \mathrm{~km} / \mathrm{s}$ and is roughly in a direction close to the $Z$ structural axis. The direction of $\mathrm{Vp}$ max and $\mathrm{Vp}$ min are directly related to the omphacite single crystal properties and the observed LPO. The [001]-axis (a fast velocity direction) is indeed preferentially oriented close to $X$ and the (010)-pole (a low velocity direction) is statistically oriented close to $Z$. The P-wave anisotropy is weak, generally less than $3 \%$.

The $\mathrm{S}$-wave anisotropy is also very weak (less than $2 \%$ ) and characterized by complex patterns. However, most of the samples (excepted S522) show directions of highest anisotropy concentrated in four zones at $45^{\circ}$ between $X, Y$ and $Z$. Although the orientation of the fast $\mathrm{S}$-wave polarization plane depends strongly on the orientation of the incoming S-wave with respect to the structural fabric, polarization planes tend to be parallel to the foliation.

For sample SL50, we calculated the seismic properties of omphacite aggregate (100\% omphacite) and velocities calculation, ignoring the contribution of quartz (75\% omphacite, $25 \%$ garnet; Table 3 ). Despite a high seismic anisotropy of omphacite single crystal and a significant omphacite LPO, the seismic anisotropy of omphacite aggregate is very weak $(\mathrm{AVp}=1.90 \%$ and $\mathrm{AVs} \max =2.52 \%)$. The contribution of garnet $(25 \%)$ increases the P- and $\mathrm{S}$-waves velocities but reduces the overall seismic anisotropy $(\mathrm{AVp}=1.30 \%$ and $\mathrm{AVs} \max =1.80 \%)$.

Table 3

Seismic properties of eclogite samples

\begin{tabular}{|c|c|c|c|c|c|c|c|c|c|c|c|}
\hline Samples & $\begin{array}{l}\mathrm{Vp} \max \\
(\mathrm{km} / \mathrm{s})\end{array}$ & $\begin{array}{l}\mathrm{Vp} \min \\
(\mathrm{km} / \mathrm{s})\end{array}$ & $\begin{array}{l}\mathrm{Vp} / / Z \\
(\mathrm{~km} / \mathrm{s})\end{array}$ & $\begin{array}{l}\mathrm{AVp} \\
(\%)\end{array}$ & $\begin{array}{l}\text { Vs1 max } \\
(\mathrm{km} / \mathrm{s})\end{array}$ & $\begin{array}{l}\text { Vs1 min } \\
(\mathrm{km} / \mathrm{s})\end{array}$ & $\begin{array}{l}\mathrm{Vs} 2 \text { max } \\
(\mathrm{km} / \mathrm{s})\end{array}$ & $\begin{array}{l}\mathrm{Vs} 2 \mathrm{~min} \\
(\mathrm{~km} / \mathrm{s})\end{array}$ & $\begin{array}{l}\text { AVs max } \\
(\%)\end{array}$ & $\begin{array}{l}\text { Omph/grt } \\
(\%)\end{array}$ & $\begin{array}{l}\text { Density } \\
\left(\mathrm{kg} / \mathrm{m}^{3}\right)\end{array}$ \\
\hline AB.E & 8.75 & 8.53 & 8.54 & 2.5 & 4.97 & 4.94 & 4.95 & 4.90 & 1.25 & $70 / 30$ & 3490 \\
\hline Eclo 01 & 8.58 & 8.47 & 8.49 & 1.3 & 4.91 & 4.88 & 4.9 & 4.87 & 0.74 & $60 / 30 / 10^{\mathrm{a}}$ & 3497 \\
\hline$\gamma 4129$ & 8.71 & 8.54 & 8.59 & 1.9 & 4.98 & 4.93 & 4.94 & 4.92 & 1.25 & $70 / 30$ & 3490 \\
\hline$\gamma 3638$ & 8.66 & 8.56 & 8.57 & 1.2 & 4.98 & 4.93 & 4.94 & 4.91 & 1.07 & $75 / 25$ & 3462 \\
\hline G3 & 8.67 & 8.53 & 8.53 & 1.7 & 4.97 & 4.93 & 4.95 & 4.92 & 0.87 & $75 / 25$ & 3462 \\
\hline B6 & 8.72 & 8.62 & 8.63 & 1.2 & 4.99 & 4.93 & 4.95 & 4.92 & 1.41 & $60 / 40$ & 3544 \\
\hline Norv.1 & 8.68 & 8.57 & 8.63 & 1.3 & 4.99 & 4.92 & 4.96 & 4.9 & 1.74 & $70 / 30$ & 3490 \\
\hline S522 & 8.73 & 8.48 & 8.50 & 2.9 & 4.97 & 4.93 & 4.95 & 4.91 & 1.18 & $75 / 25$ & 3462 \\
\hline S509 & 8.75 & 8.56 & 8.59 & 2.3 & 5 & 4.92 & 4.94 & 4.9 & 1.66 & $70 / 30$ & 3490 \\
\hline SL50 & 8.51 & 8.39 & 8.43 & 1.4 & 4.94 & 4.87 & 4.91 & 4.84 & 2.02 & $70 / 20 / 10^{\mathrm{b}}$ & 3368 \\
\hline SL50 & 8.68 & 8.56 & 8.61 & 1.3 & 5.00 & 4.92 & 4.96 & 4.90 & 1.80 & $75 / 25$ & 3462 \\
\hline SL50 & 8.61 & 8.45 & 8.52 & 1.9 & 5.00 & 4.89 & 4.95 & 4.86 & 2.52 & 100 (omph) & 3327 \\
\hline
\end{tabular}

Vp//Z: P-wave velocity normal to the foliation; AVp: P-wave anisotropy; omph/grt: modal proportion of omphacite and garnet used for the calculation. Calculations are performed using the Voigt average. For sample SL50, also are calculated the seismic properties ignoring the contribution of quartz ( $75 \%$ omphacite, $25 \%$ garnet) and the seismic properties of omphacite aggregate $(100 \%$ omphacite).

${ }^{\text {a }}$ Isotropic epidote $(10 \%)$ has been taken into account to calculate the seismic properties.

${ }^{b}$ Quartz $(10 \%)$ has been taken into account to calculate the seismic properties. 


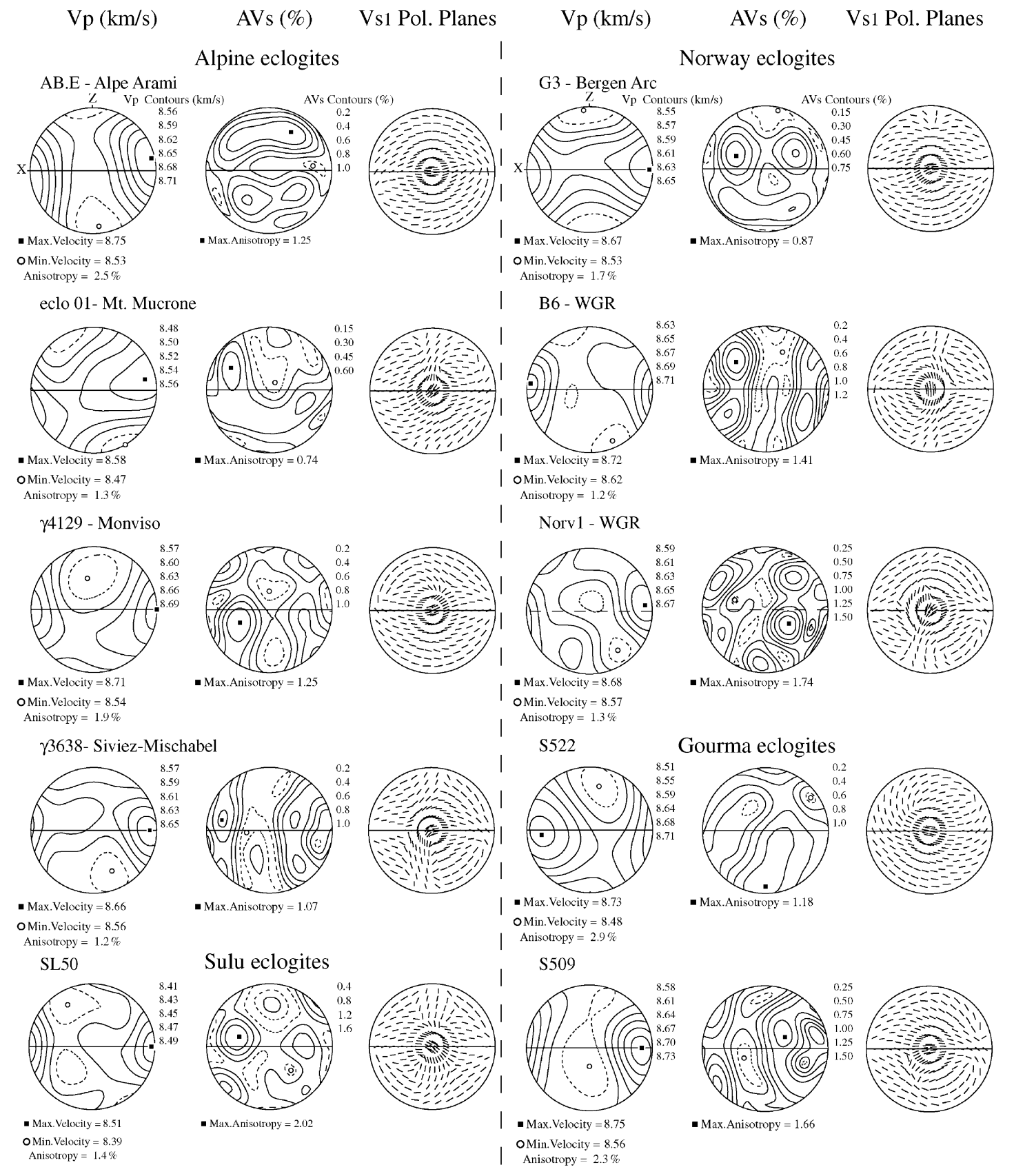

Fig. 8. Seismic properties of eclogite samples. Equal area projection in the structural reference frame $X, Y, Z$, (lower hemisphere).

The effect of quartz is to decrease the P- and Swaves velocities and slightly increase the P- and Swave anisotropies. The average seismic properties and the corresponding elastic constants of the 10 selected samples have been calculated (Fig. 9 and Table 4). This mean sample is almost isotropic, Pwave anisotropy is $1.4 \%$ and $\mathrm{S}$-wave anisotropy is less than $1 \%$. 


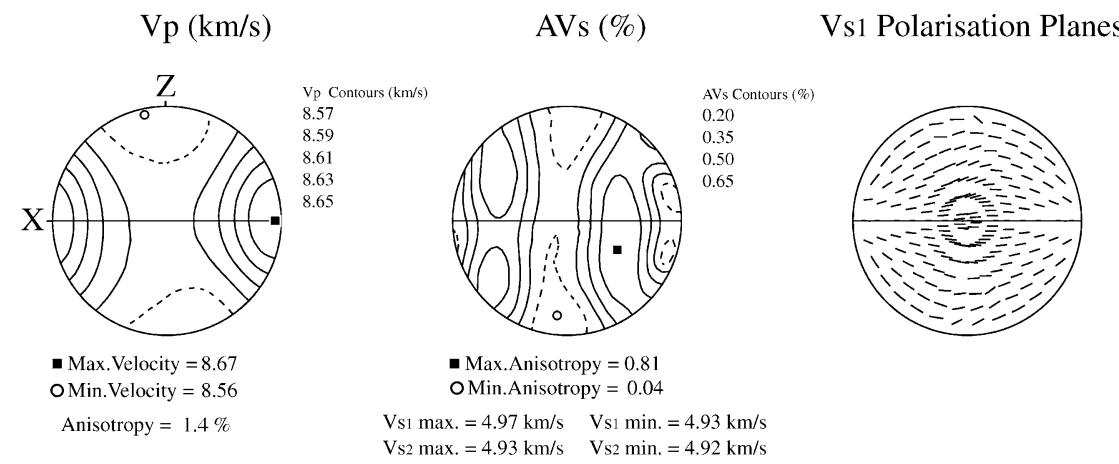

Fig. 9. Average seismic properties from the 10 eclogite samples studied in this work. Equal area projection in the structural reference frame $X, Y$, $Z$, (lower hemisphere).

\subsection{Comparison between calculated and measured eclogite seismic velocities}

In their compilation of laboratory measurements in continental crustal rocks, Christensen and Mooney (1995) have highlighted the narrow range of P-wave velocity variation in eclogite facies rocks compared to others major metamorphic rocks. For these authors,

Table 4

Elastic constants (Cij) of the average of the 10 eclogite samples

\begin{tabular}{lc}
\hline Modulus & Cij $(\mathrm{GPa})$ \\
\hline $\mathrm{C}_{11}$ & 254.57 \\
$\mathrm{C}_{12}$ & 86.80 \\
$\mathrm{C}_{13}$ & 86.83 \\
$\mathrm{C}_{14}$ & -0.16 \\
$\mathrm{C}_{15}$ & 0.12 \\
$\mathrm{C}_{16}$ & -0.30 \\
$\mathrm{C}_{22}$ & 261.43 \\
$\mathrm{C}_{23}$ & 87.77 \\
$\mathrm{C}_{24}$ & 0.37 \\
$\mathrm{C}_{25}$ & 0.01 \\
$\mathrm{C}_{26}$ & -0.11 \\
$\mathrm{C}_{33}$ & 256.07 \\
$\mathrm{C}_{34}$ & 0.07 \\
$\mathrm{C}_{35}$ & 0.05 \\
$\mathrm{C}_{36}$ & -0.08 \\
$\mathrm{C}_{44}$ & 84.70 \\
$\mathrm{C}_{45}$ & -0.02 \\
$\mathrm{C}_{46}$ & -0.02 \\
$\mathrm{C}_{55}$ & 84.29 \\
$\mathrm{C}_{56}$ & -0.11 \\
$\mathrm{C}_{66}$ & 84.31 \\
\hline
\end{tabular}

Density of this mean aggregate of eclogite: $d=3487 \mathrm{~kg} / \mathrm{m}^{3}$. mean P-wave velocities in eclogites range between 7.9 and $8.5 \mathrm{~km} / \mathrm{s}$ at pressure corresponding to a depth of $20 \mathrm{~km}$. Compared to these measured velocities, our calculated P-wave velocities are slightly faster, around $8.6 \mathrm{~km} / \mathrm{s}$. As for the P-waves, the average calculated S-wave velocities (around $4.9 \mathrm{~km} / \mathrm{s}$ ) are higher than seismic velocities, which are measured around 4.5 $\mathrm{km} / \mathrm{s}$ by Kern et al. (1999) and by Manghnani et al. (1974). Such discrepancy may be related to the presence of minor phases, grains boundaries, microcracks, and to alteration of the main minerals whose effects are not taken into account in the calculations, and may affect velocity measurements. Compositional layering may also induce significant differences between calculations and measurements (Mauler et al., 2000). In addition, we calculated velocities with the Voigt average that usually gives an upper bound for seismic velocities (Crosson and Lin, 1971; Mainprice and Humbert, 1994). Sample G3 is interesting since direct laboratory measurements were performed by Fountain et al. (1994) on samples collected in the same area. The calculated mean P-wave velocity for this sample is $8.6 \mathrm{~km} / \mathrm{s}$, close to the fastest velocities, about $8.5 \mathrm{~km} / \mathrm{s}$, measured at $600 \mathrm{MPa}$ confining pressure in the eclogite from this locality (Fountain et al., 1994). Both calculated and measured Vp anisotropy are weak, respectively, about $2 \%$ and $3 \%$ in average. Moreover, calculated and measured Pwave velocities display roughly the same anisotropy pattern characterized by fast velocities parallel to the lineation, and low velocities normal to the foliation (Manghnani et al., 1974; Fountain et al., 1994; Kern et al., 1999; Mauler et al., 2000). This suggests that, in 
eclogite, the P-wave velocity pattern is primarily controlled by omphacite LPO.

\section{Discussion}

Although the primary goal of this paper is to characterize the 3D seismic properties of eclogite rocks, a potential use of these data is to discuss the detectability of eclogite bodies within the crust and the mantle. Our calculations show that eclogites are systematically quasi isotropic. This absence of anisotropy implies that eclogites are poor candidates to generate any detectable shear wave splitting that could be used to indirectly detect eclogites bodies. Although the nondetection of a geophysical signal (here the splitting of shear wave ) is always hard to interpret in a field experiment, eclogite bodies are characterized by high density, high seismic velocities and very small seismic anisotropies. Since upper mantle rocks are generally much more anisotropic, this isotropy is the main criterion that may distinguish peridotite bodies from eclogites.

On the basis of geothermal and seismic considerations, possible eclogite/peridotite contact at the base of the continental crust has been suggested by several authors (e.g. Furlong and Fountain, 1986; Griffin and O'Reilly, 1987). Moreover, eclogite layers, as relicts of subduction zones, may be preserved within the crust or the mantle. Preservation of these layers depends on the protolith composition and on the thermal gradient. If large eclogite layers escape from the thermal reactivation, the interface eclogite/crustal rocks could generate bright seismic reflectors that might be misinterpreted as a Moho discontinuity.

In order to quantify the reflectivity of such eclogites in contact with crustal or mantle rocks, we present simple geometric models, taking into account the seismic properties issued from our calculations. We evaluate the reflectivity of simple lithological interfaces between eclogite and various lithologies (Table 5). The reflection coefficient (Rc) is calculated for a seismic wave arriving at vertical incidence on a horizontal interface. For this simplest case, a simple relation allows to calculate the reflection coefficient: $\mathrm{Rc}=\left[\mathrm{Vp}(/ / Z)_{1} \rho_{1}-\mathrm{Vp}(/ / Z)_{2} \rho_{2}\right] /\left[\mathrm{Vp}(/ / Z)_{1} \rho_{1}+\mathrm{Vp}(/ /\right.$ $Z)_{2} \rho_{2}$ ]. To evaluate the influence of seismic anisotropy, we determined in a first calculation the reflec-
Table 5

Absolute reflection coefficients $|\mathrm{Rc}|$ calculated from anisotropic Pwave velocity and from isotropic P-wave velocity

\begin{tabular}{lll}
\hline Interfaces & $\begin{array}{l}|\mathrm{Rc}| \text { coefficient } \\
\text { for the anisotropic } \\
\text { medium }\end{array}$ & $\begin{array}{l}|\mathrm{Rc}| \text { coefficient } \\
\text { for the isotropic } \\
\text { medium }\end{array}$ \\
\hline Eclo/gneiss $^{2}$ & 0.30 & 0.30 \\
Eclo/kinzigite $^{1}$ & 0.28 & 0.26 \\
Eclo/magmatic gabbro $^{1}$ & 0.19 & 0.20 \\
Eclo/diorite $^{1}$ & 0.20 & 0.20 \\
Eclo/stronalite $^{1}$ & 0.14 & 0.14 \\
Eclo/mean crust $^{3}$ & 0.26 & 0.25 \\
Eclo/peridotite $^{4}$ & 0.06 & 0.04 \\
& & \\
Mean crust/peridotite & 0.2 & 0.2 \\
\hline
\end{tabular}

The $\mathrm{P}$-wave propagation is assumed to be vertical and the foliation horizontal. For eclogite (eclo), $\mathrm{Vp}$ is the average of velocities normal to foliation. In the anisotropic case $\mathrm{Vp}=8.56 \mathrm{~km} / \mathrm{s}$, and in the isotropic case $\mathrm{Vp}=8.6 \mathrm{~km} / \mathrm{s}$. References for the others rocks: ${ }^{1}$ Barruol and Mainprice (1993a); ${ }^{2}$ Barruol et al (1992); ${ }^{3}$ Barruol and Mainprice (1993b); ${ }^{4}$ Vauchez and Garrido (2001).

tion coefficient, taking into account the anisotropic seismic properties of the rocks, and in a second calculation, the isotropic properties of the rocks. In the anisotropic case, Rc calculation is carried out using the P-wave velocity in a direction normal to the foliation. The seismic velocities of typical crustal lithologies (gneiss, kinzigite, gabbro, diorite and stronalite) were taken from the literature (Barruol et al., 1992; Barruol and Mainprice, 1993a,b). The "mean crust" (plagioclase 35\%, quartz $15 \%$, biotite $7 \%$, clinopyroxene $8 \%$, amphibole $15 \%$, K-feldspar $20 \%$ (isotropic)) corresponds to the average crustal composition given by Anderson (1989). We also investigated the reflectivity of an eclogite body embedded within the mantle. The seismic properties of this upper mantle rock correspond to those of a continental lherzolite sampled in the Ronda massif (Vauchez and Garrido, 2001). We selected this lherzolite sample on its typical porphyroclastic texture and LPO and on its modal composition (65\% olivine, $20 \%$ orthopyroxene, $10 \%$ clinopyroxene and $2 \%$ spinel). Seismic Pwave properties of this peridotite are characterized by a maximum velocity $(8.55 \mathrm{~km} / \mathrm{s})$ parallel to the lineation, a minimum velocity $(8.09 \mathrm{~km} / \mathrm{s})$ normal to the foliation and by a P-wave anisotropy of $5.5 \%$. We summarize in Table 5 the calculated Rc for the various interfaces. The eclogite/crustal rocks interfaces as well 
as the peridotite/"mean crust" interface systematically display very high reflection coefficient (higher than 0.1 ). This strong reflectivity is primarily due to the density contrast between eclogite (density of $3487 \mathrm{~kg} /$ $\mathrm{m}^{3}$ on average) or peridotite (density of $3310 \mathrm{~kg} / \mathrm{m}^{3}$ ) and the crustal rocks (mean density of $2700 \mathrm{~kg} / \mathrm{m}^{3}$ ). Reflectivity of the eclogite/kinzigite interface as well as eclogite/"main crust"/interface is slightly higher when the seismic anisotropy of the rocks is taken into account. This is due to the fact that these rock types are characterized by high velocities parallel to the foliation and by lower velocities for directions at high angle from the foliation. Therefore, in the isotropic case, the velocity along the $Z$ structural directions is higher than in the anisotropic case, and the Rc slightly lower. On the other hand, the eclogite/peridotite interface is characterized by a much weaker reflection coefficient $(\mathrm{Rc}=0.06)$. Such reflection magnitude could be almost impossible to detect, particularly at a large depth by seismic reflection techniques. This interface becomes even less reflective when the mantle seismic anisotropy is not taken into account. Such difference between an anisotropic $(\mathrm{Rc}=0.06)$ and isotropic medium $(\mathrm{Rc}=0.04)$ suggests that the eclogite/"upper mantle" reflectivity could be sensitive to the direction of the seismic wave propagation.

The main result of these simple calculations is that an eclogite body embedded in the crust would generate very strong seismic reflections, which could help to identify eclogite bodies but which may be misinterpreted in terms of Moho discontinuity. On the other hand, our calculations show that an eclogite body within the upper mantle would generate weak seismic reflection and might therefore remain almost invisible to vertical seismic reflection techniques. Moreover, the $\mathrm{Vp} / \mathrm{Vs}$ ratio and the corresponding Poisson ratio $\sigma$ (Christensen, 1996) calculated for eclogite $\left((\mathrm{Vp} / \mathrm{Vs})_{\text {iso }}=1.74\right)$ and for the Ronda lherzolite $\left((\mathrm{Vp} / \mathrm{Vs})_{\text {iso }}=1.71\right)$ are very close and therefore not discriminatory.

\section{Conclusion}

Although the studied eclogites come from orogenic domains of contrasted age and geodynamic evolution, garnet and omphacite LPO patterns display similar main characteristics. Garnet appears to be almost randomly oriented, whereas omphacite develops strong LPO characterized by the [001]-axes concentrated sub-parallel to the lineation and the (010)-poles roughly normal to the foliation. We suggest that these LPOs formed in relation with the deformation of eclogites through dislocation creep. This statement is supported by a numerical model result, which shows that omphacite lattice-preferred orientation can develop through plastic deformation by dominant activation of $1 / 2\langle 110\rangle\{1 \overline{1} 0\}$, [001] (110) and [001] (100) slip systems, in agreement with TEM observations of naturally deformed omphacite. LPO of omphacite may therefore help to constrain the tectonic processes active during the high-pressure deformation of eclogites.

Seismic properties of eclogites are mostly governed by omphacite LPO. As variations of these LPO in our dataset are rather limited, the resulting seismic properties are almost similar. Although seismic anisotropy of $\mathrm{P}$-waves is weak, the fast propagation is generally parallel to the rock lineation and the low velocity propagation is normal to the foliation. For P-waves, the relationship between seismic properties and the LPO is straightforward: the fast propagation direction is associated to the concentration of [001]-axes parallel to the lineation, and the slow propagation direction is associated to a concentration of (010)-poles perpendicular to the foliation. The Pand $\mathrm{S}$-wave anisotropies are very weak, less than $2 \%$. The $\mathrm{S}$-wave maximum polarization anisotropy is preferentially concentrated at $45^{\circ}$ between the $X, Y$ and $Z$-structural axes. Orientation of the fast $\mathrm{S}$-wave polarization plane is poorly correlated with the structural framework but tends to be parallel to the foliation. The velocity patterns and the anisotropy magnitude are in rather good agreement with laboratory-derived seismic velocities. Average P-wave velocities $(8.6 \mathrm{~km} / \mathrm{s})$ and S-wave velocities $(4.9 \mathrm{~km} /$ s) are similar to the highest velocities measured in eclogites. Part of the difference between calculated and measured velocities may be related to minor mineral phases and microfracturing, which are not taken into account in our calculation.

Finally, estimation of reflection coefficient highlights the fact that an eclogite body within the upper mantle would be difficult to detect by seismic reflection techniques, whereas eclogite bodies embedded within the crust would generate very strong seismic 
reflections. The eclogite isotropy might be a distinctive parameter since peridotites are characterized by a large seismic anisotropy, whereas the intrinsic seismic anisotropy of eclogite is usually very weak.

\section{Acknowledgements}

We thank R. Caby, B. Ildefonse, M. Faure and L. Labrousse for providing the eclogite samples. Thanks to C. Nevado who made tens of wonderful thin sections and EBSD polishing that allowed this study. R. Caby and A. Tommasi are gratefully acknowledged for fruitful discussions. We thank A. Mauler and an anonymous reviewer for constructive comments on the manuscript. This work benefited from a grant from CNRS/INSU program "Intérieur de la Terre, Exhumation des roches profondes"; contribution INSU no. 282. The crystal orientation measurements were made using the Laboratoire de Tectonophysique EBSD/ SEM system funded by grants from CNRS/INSU, Universite Montpellier II, the NSF project \#EAR9526840 "Anatomy of an Archean craton" and ISTEEM. J.B. benefited from a $\mathrm{PhD}$ fellowship from the CAPES-Brazil.

\section{References}

Abalos, B., 1997. Omphacite fabric variation in the Cabo Ortegal eclogite (NW Spain): relationship with strain symmetry during high-pressure deformation. J. Struct. Geol. 19, 621-637.

Adams, B.L., Wright, S.I., Kunze, K., 1993. Orientation imaging: the emergence of a new microscopy. Metall. Trans. 24A, 819-831.

Andersen, T.B., 1998. Extensional tectonics in the Caledonides of southern Norway, an overview. Tectonophysics 285, 333-351.

Anderson, D.L., 1989. Theory of the Earth. Ed. Blackwell, Oxford.

Austrheim, H., 1987. Eclogitization of the lower crustal granulites by fluid migration through shear zones. Earth Planet. Sci. Lett. $81,221-232$.

Austrheim, H., 1991. Eclogite formation and dynamics of crustal roots under continental collision zones. Terra Nova 3, 492-499.

Austrheim, H., Griffin, W.L., 1985. Shear deformation and eclogite formation within granulite facies anorthosites of the Bergen Arcs, western Norway. Chem. Geol. 50, 267-281.

Babuska, V., 1972. Elasticity and anisotropy of dunite and bronzitite. J. Geophys. Res. 77, 6955-6965.

Babuska, V., Fiala, J., Kumazawa, M., Ohno, I., 1978. Elastic properties of garnet solid-solution series. Phys. Earth Planet. Inter. $16,157-176$.

Barruol, G., Mainprice, D., 1993a. 3D seismic velocities calculated from LPOs and reflectivity of a lower crustal section-example of the Val Sesia (Ivrea Zone, Northern Italy). Geophys. J. Int. 115, 1169-1188.

Barruol, G., Mainprice, D., 1993b. A quantitative evaluation of the contribution of crustal rocks to the shear wave splitting of teleseismic SKS waves. Phys. Earth Planet. Inter. 78, 281-300.

Barruol, G., Mainprice, D., Kern, H., Saint Blanquat, M., Compte, P., 1992. 3D seismic study of a ductile shear zone from laboratory and petrofabric data (Saint Barthélémy Massif, Northern Pyrénées, France). Terra Nova 4, 63-76.

Bascou, J., Tommasi, A., Mainprice, D., 2001. Plastic deformation and development of clinopyroxene lattice preferred orientations in eclogites. J. Struct. Geol. (in press).

Ben Ismaïl, W., Mainprice, D., 1998. An olivine fabric database: an overview of upper mantle fabrics and seismic anisotropy. Tectonophysics 296, 145-157.

Bhagat, S.S., Bass, J.D., Smyth, J.R., 1992. Single-crystal elastic properties of omphacite- $\mathrm{C} 2 / \mathrm{c}$ by Brillouin spectroscopy. J. Geophys. Res. 97, 6843-6848.

Bouchez, J.L., Nicolas, A., Lister, G., 1983. Fabric asymmetry and shear sense in movement zones. Geol. Rundsch. 72, 401-419.

Boundy, T.M., Fountain, D.M., Austrheim, H., 1992. Structural development and petrofabrics of eclogite facies shear zones, Bergen Arcs, western Norway: implications for deep crustal deformational processes. J. Metamorph. Geol. 10, 127-146.

Buatier, M., Van Roermund, H.L.M., Drury, M.R., Lardeaux, J.M., 1991. Deformation and recrystallization mechanisms in naturally deformed omphacites from the Sesia-Lanzo zone; geophysical consequences. Tectonophysics 195, 11-27.

Butler, R.W.H., 1986. Thrust tectonics, deep structure and crustal subduction in the Alps and Himalayas. J. Geol. Soc. London 143, 857-873.

Caby, R., 1994. Precambrian coesite from northern Mali: first record and implications for plate tectonics in the trans-Saharan segment of the Pan-African belt. Eur. J. Mineral. 6, 235-244.

Caby, R., Kienast, J.R., Saliot, P., 1978. Structure, métamorphisme et modèle d'évolution tectonique des Alpes occidentales. Rev. Geogr. Phys. Geol. Dyn. 20, 307-322.

Christensen, N.I., 1996. Poisson's ratio and crustal seismology. J. Geophys. Res. 101, 3139-3156.

Christensen, N.I., Mooney, W.D., 1995. Seismic velocity structure and composition of the continental crust: a global review. J. Geophys. Res. 100, 9761-9788.

Clark, J.R., Appleman, D.E., Papike, J.J., 1969. Crystal-chemical characterization of clinopyroxenes based on eight new structure refinements. Mineral. Soc. Am., Spec. Pap. 2, 31-50.

Compagnoni, R., Dal Piaz, G.Y., Hunziker, J.C., Gosso, G., Lombardo, B., Williams, P.F., 1977. The Sesia-Lanzo zone: a slice of continental crust with alpine high pressure-low temperature assemblage in the Western Italien Alps. Rend. Soc. Ital. Mineral. Petrol. 33, 281-334.

Crosson, R.S., Lin, J.W., 1971. Voigt and Reuss prediction of anisotropic elasticity of dunite. J. Geophys. Res. 76, 570-578.

Dingley, D.J., Field, D.P., 1997. Electron backscatter diffraction and orientation imaging microscopy. Mater. Sci. Technol. 13, 69-78.

Ernst, W.G., 1977. Mineralogic study of eclogitic rocks from Alpe 
Arami, Lepontine Alps, southern Switzerland. J. Petrol. 18, 371-398.

Faure, M., Lin, W., Le Breton, N., 2001. Where is the North ChinaSouth China block boundary in eastern China? Geology 29, 119-122.

Fountain, D.M., Boundy, T.M., Austrheim, H., Rey, P., 1994. Eclogite-facies shear zones - deep crustal reflectors? Tectonophysics $232,411-424$.

Furlong, K.P., Fountain, D.M., 1986. Continental crust underplatting: thermal considerations and seismic-petrologic consequences. J. Geophys. Res. 91, 8285-8294.

Godard, G., Van Roermund, H.L.M., 1995. Deformation-induced clinopyroxene from eclogites. J. Struct. Geol. 17, 1425-1443.

Griffin, W.L., O'Reilly, S.Y., 1987. Is the continental Moho the crust-mantle boundary? Geology 15, 241-244.

Heinrich, C.A., 1986. Eclogite facies regional metamorphism of hydrous mafic rocks in the Central Alpine Adula Nappe. J. Petrol. 27, 123-154.

Helmstaedt, H., Anderson, O.L., Gavasci, A.T., 1972. Petrofabric studies of eclogite, spinel-websterite, and spinel-lherzolite xenoliths from kimberlite-bearing breccia pipes in southeastern Utah and northeastern Arizona. J. Geophys. Res. 77, 4350-4365.

Kern, H., Gao, S., Jin, Z., Popp, T., Jin, S., 1999. Petrophysical studies on rocks from the Dabie ultrahigh-pressure (UHP) metamorphic belt, Central China: implications for the composition and delamination of the lower crust. Tectonophysics 301, 191-215.

Krieger Lassen, N.C., 1996. The relative precision of crystal orientations measured from electron backscattering patterns. J. Microsc. 181, 72-81.

Krogh, E.J., 1982. Metamorphic evolution deduced from mineral inclusions and compositional zoning in garnets from Norwegian country-rock eclogites. Lithos $15,305-321$.

Lardeaux, J.M., Gosso, G., Kienast, J.R., Lombardo, B., 1982. Relations entre le métamorphisme et la déformation dans la zone de Sesia-Lanzo (Alpes occidentales) et le problème de l'éclogitisation de la croûte continentale. Bull. Soc. Geol. Fr. 24, $793-800$.

Laubscher, H., 1990. The problem of the Moho in the Alps. Tectonophysics $182,9-20$.

Lebensohn, R.A., Tomé, C.N., 1993. A self-consistent anisotropic approach for the simulation of plastic deformation and texture development of polycrystals: application to zirconion alloys. Acta Metall. Mater. 41, 2611-2624.

Lloyd, G.E., Schmidt, N.H., Mainprice, D., Prior, D.J., 1991. Crystallographic textures. Mineral. Mag. 55, 331-345.

Mainprice, D., 1990. A FORTRAN program to calculate seismic anisotropy from the lattice preferred orientation of minerals. Comput. Geosci. 16, 385-393.

Mainprice, D., Humbert, M., 1994. Methods of calculating petrophysical properties from lattice preferred orientation data. Surv. Geophys. 15, 575-592.

Mainprice, D., Nicolas, A., 1989. Development of shape and lattice preferred orientations: application to the seismic anisotropy of the lower crust. J. Struct. Geol. 11, 175-189.

Mainprice, D., Lloyd, G., Casey, M., 1993. Individual orientation measurements in quartz polycrystals: advantages and limitations for texture and petrophysical property determinations. J. Struct. Geol. 15, 1169-1187.

Manghnani, M.H., Ramananantoandro, R., Clark Jr., S.P., 1974. Compressional and shear wave velocities in granulite facies rocks and eclogites to 10 kbar. J. Geophys. Res. 79, $5427-$ 5446.

Mauler, A., Kunze, K., Burg, J.P., Philippot, P., 1998. Identification of EBSD patterns in a monoclinic solid-state solution series: example of omphacite. Mater. Sci. Forum 275, 705-710.

Mauler, A., Burlini, L., Kunze, K., Philippot, P., Burg, J.P., 2000. Pwave anisotropy in eclogites and relationship to the omphacite crystallographic fabric. Phys. Chem. Earth. 25, 119-126.

McSkimin, H.J., Anreatch, J.R., Thurston, R.N., 1965. Elastic moduli of quartz versus hydrostatic pressure at $25^{\circ}$ and $-195.8^{\circ} \mathrm{C}$. J. Appl. Phys. 36, 1624-1632.

Messiga, B., Kienast, J.R., Rebay, G., Riccardi, M.P., Tribuzzio, R., 1999. Cr-rich magnesiochloritoid eclogites from the Monviso ophiolites (Western Alps, Italy). J. Metamorph. Geol. 17, 287-299.

Möckel, J.R., 1969. Structural petrology of the garnet-peridotite of Alpe Arami (Ticino, Switzerland). Leidsche Geol. Meded. 42, 61-130.

Nicolas, A., Christensen, N.I., 1987. Formation of anisotropy in upper mantle peridotites - a review. In: Fuchs, K., Froidevaux, C. (Eds.), Composition, Structure and Dynamics of the Lithosphere-Asthenosphere System. Am. Geophys. Un., Washington, DC, pp. 111-123.

Nicolas, A., Boudier, F., Boullier, A.M., 1973. Mechanism of flow in naturally and experimentally deformed peridotites. Am. J. Sci. 273, 853-876.

Nicolas, A., Polino, R., Hirn, A., Nicolich, R., 1990. ECORSCROP traverse and the deep structure of the western Alps: a synthesis. Mem. Soc. Geol. Fr. 156, 15-27.

Philippot, P., Kienast, J.R., 1989. Chemical-microstructural changes in eclogitic shear zones, Monviso (Western Alps), as indicators of strain history, mechanisms and scales of mass transfer. Lithos 23 , 179-200.

Raterron, P., Doukhan, N., Jaoul, O., Doukhan, J.C., 1994. High temperature deformation of diopside IV: predominance of $\{110\}$ glide above $1000{ }^{\circ} \mathrm{C}$. Phys. Earth Planet. Inter. 82, 209-222.

Rubie, D.C., 1984. A thermal-tectonic model for high-pressure metamorphism and deformation in the Sesia Zone, Western Alps. J. Geol. 92, 21-36.

Ryzhova, T.V., Aleksandrov, K.S., Korobkova, V.M., 1966. The elastic properties of rock-forming minerals V: additional data on sillicates. Izv. Earth Phys. 2, 63-65.

Schmidt, N.H., Olesen, N.Ø., 1989. Computer-aided determination of crystal-lattice orientation from electron-channeling patterns in the SEM. Can. Mineral. 27, 15-22.

Thélin, P., Sartori, M., Lengeler, R., Schaerer, J.P., 1990. Eclogites of Paleozoic or early Alpine age in the basement of the Penninic Siviez-Mischabel nappe, Wallis, Switzerland. Lithos 25, $71-88$.

Tommasi, A., Mainprice, D., Canova, G., Chastel, Y., 2000. Viscoplastic self-consistent and equilibrium-based modeling of olivine 
lattice preferred orientations: implications for upper mantle seismic anisotropy. J. Geophys. Res. 105, 7893-7908.

Van Roermund, H.L.M., 1983. Petrofabrics and microstructures of omphacites in a high temperature eclogite from the Swedish Caledonides. Bull. Mineral. 106, 709-713.

Van Roermund, H.L.M., Boland, J.N., 1981. The dislocation substructures of naturally deformed omphacites. Tectonophysics 78 , $403-418$.

Vauchez, A., Garrido, C.J., 2001. Seismic properties of an asthenospherized lithospheric mantle: constraints from lattice pre- ferred orientations in peridotite from the Ronda Massif. Earth Planet. Sci. Lett. 192, 235-249.

Warner, M., Morgan, J., Barton, P., Morgan, P., Price, C., Jones, K., 1996. Seismic reflections from the mantle represent relict subduction zones within the continental lithosphere. Geology 24, 39-42.

Zhang, R.Y., Hirajima, T., Banno, S., Cong, B., Liou, J.G., 1995. Petrology of ultrahigh-pressure rocks from the southern $\mathrm{Su}-\mathrm{Lu}$ region, eastern China. J. Metamorph. Geol. 13, $659-675$. 